\title{
STUDI EKSPERIMEN MODEL PEMBELAJARAN KOOPERATIF KOMBINASI TIPE STAD (STUDENT TEAMS ACHIEVEMENT DIVISION) DAN TGT (TEAMS GAMES TOURNAMENT) DALAM MENINGKATKAN MOTIVASI DAN AKTIVITAS BELAJAR MATEMATIKA PESERTA DIDIK (Penelitian pada SMP Negeri 3 Bantul Yogyakarta)
}

\author{
Wakitri
}

SMP Negeri 3 Bantul Yogyakarta

E-mail: putrijukri5@yahoo.co.id

\begin{abstract}
Abstrak
Penelitian ini bertujuan untuk mengetahui perbedaan peningkatan motivasi dan aktivitas belajar peserta didik yang belajar dengan model pembelajaran tipe STAD dikombinasikan TGT dengan peserta didik yang belajar dengan model pembelajaran konvensional. Metode penelitian menggunakan penelitian kuantitatif dengan pendekatan Quasi Experimental Design. Sampel eksperimen sebanyak 32 peserta didik dan sampel kontrol sebanyak 30 peserta didik. Penelitian dilaksanakan di SMP Negeri 3 Bantul. Data dikumpulkan melalui angket dan observasi. Analisis data menggunakan teknik analisis deskriptif kuantitatif dan uji-t dengan taraf signifikan 5\%. Hasil uji beda dengan rumus ttes memperlihatkan bahwa peningkatan motivasi belajar nilai $\mathrm{p}(\mathrm{sig})$ pada $\mathrm{t}$ adalah 0,000 $<0,05$. Nilai $\mathrm{p}(\mathrm{sig})$ pada $\mathrm{t}$ untuk peningkatan aktivitas belajar adalah $0,000<0,05$ sehingga ada perbedaan rata-rata motivasi dan aktivitas belajar antara kelompok kontrol dan kelompok eksperimen setelah penerapan model pembelajaran tipe STAD dikombinasikan dengan TGT. Kelompok eksperimen mengalami peningkatan rata-rata aktivitas dan motivasi belajar lebih tinggi dari pada kelompok kontrol..
\end{abstract}

Kata kunci: pembelajarn, motivasi, aktivitas, STAD, TGT

\begin{abstract}
This research aims to discover the differences and improvements between learning motivation and activity of the students who are taught with the combination of STAD and TGT with the students who are taught with conventional model. This research uses quantitative model with Quasi Experimental design. This research was conducted in SMP3 Bantul, with 32 students as experiment samples and 30 students as control samples. The data were collected through questionnaires and observation. Then, the data were analyzed by using descriptive quantitative technique and T-test with significance of 5\%. The result of $T$-test shown that the value of $p($ sig) for motivation $t$ is $0.000<0,05$ The value of $p$ (sig) for learning activity $t$ is $0.000<0,05$, It can be concluded that there are any differences in learning motivation and activity between control sample and experimental sample after the implementation of combination method between STAD and TGT. The result of this research shown that the average learning activity and motivation of the experiment students are increased.
\end{abstract}

Keywords: learning, motivation, activity, STAD, TGT

\section{Info Artikel}

Diterima Oktober 2018, disetujui November 2018, diterbitkan Desember 2018 


\section{PENDAHULUAN}

Matematika menjadi sarana melatih kemampuan berpikir logis sistematis, sebagai pembentuk sikap maupun sebagai alat untuk melatih ketelitian, ketepatan dan kecermatan kerja yang menunjang ilmu dan teknologi. Dapat dikatakan bahwa penguasaan matematika menjadi fondasi guna menguasai sains dan teknologi. Matematika juga dikatakan sebagai bahasa ilmu pengetahuan.

Namun disamping itu matematika sebagai salah satu mata pelajaran Ujian Nasinal, matematika juga dianggap sebagai mata pelajaran yang sulit dan membosankan oleh sebagian peserta didik. Padahal dalam belajar matematika sangat dibutuhkan motivasi, aktivitas dan konsentrasi yang tinggi. Peserta didik dituntut untuk lebih aktif, telaten, tekun, banyak latihan dan, penuh konsentrasi dalam proses pembelajaran.

Masalah yang dihadapi di SMP 3 Bantul saat ini adalah peserta didik memiliki motivasi untuk beraktivitas mengikuti proses pembelajaran masih belum memuaskan ditandai dengan masih ada beberapa peserta didik belum beraktivitas secara total dalam mengikuti pembelajaran yaitu terlihat adanya beberapa peserta didik yang belum mengerjakan tugas di sekolah maupun tugas rumah (PR) secara optimal, belum terbiasa mencatat hal-hal penting. Beberapa peserta didik suka bermain dan berbicara di luar materi pelajaran pada waktu kegiatan pembelajaran. Dengan keadaan demikian kegiatan pembelajaran kurang efektif karena banyak waktu pembelajaran tersita, digunakan oleh guru untuk menegur, mengingatkan dan menasehati beberapa peserta didik tersebut.

Tetapi peneliti juga tidak hanya menyalahkan peserta didik, jika dilihat dari faktor guru, proses pembelajarn selama ini memang kurang variatif, pembelajaran boleh dikatakan masih konvensional. Dalam kenyataan di lapangan, implementasi variasi model pembelajaran, bagi guru dipandang menyita banyak waktu belajar, sehingga kalau diterapkan ada kekhawatiran tidak tercapainya target kurikulum, padahal guru harus mempersiapkan peserta didik untuk mengikuti Ujian Nasional. Terkait hal itu guru belum memanfaatkan waktu untuk mencoba metode pembelajaran yang belum pernah dicobakan. Karena implementasi metode baru juga dipandang menambah beban guru karena harus menyiapkan seperangkat instrumen yang diperlukan untuk seluruh peserta didik. Sehingga pembelajaran mayoritas terlaksana secara monoton ceramah, tanya jawab, pemberian tugas, dan diskusi kelas sehingga pembelajaran terpusat pada guru, peserta didik hanya pasif mendengarkan, mencatat, mengerjakan latihan yang diberikan oleh guru.

Oleh karena itu, guru dituntut harus selalu mengefektifkan kinerjanya teknik-teknik memotivasi peserta didik untuk beraktivitas memang harus dilakukan dengan mengikuti cara kerja otak. Rangsangan atau 
sentuhan yang bersifat emosional akan menggerakkan unsur otak yang berhubungan dengan perasaan. Secara psikologis, peserta didik SMP lebih mudah memahami suatu materi atau permasalahan yang membutuhkan penalaran. Namum demikian, peserta didik SMP juga merupakan remaja yang sedang mengalami masa pubertas yang penuh gejolak dan kadang sulit ditebak. Sebaik apapun suatu rancangan belajar, pada akhirnya kembali kepada implementasinya di kelas. Dengan latar belakang masalah di atas peneliti akan mencoba solusinya dengan mengimplementasikan model pembelajaran kooperatif tipe STAD dikombinasikan dengan TGT dalam meningkatkan motivasi dan aktivitas belajar peserta didik dalam proses pembelajaran.

Implementasi STAD dimungkinkan dapat memotivasi peserta didik supaya dapat saling mendukung dan membantu satu sama lain dalam menguasai kemampuan yang diajarkan oleh guru. Jika para peserta didik ingin agar timnya mendapatkan penghargaan tim, karena tim terdiri dari peserta didik dengan kemampuan heterogen, mereka harus membantu teman satu timnya untuk mempelajari materinya. Mereka harus mendukung teman satu timnya untuk bisa melakukan yang terbaik, menunjukkan norma bahwa belajar itu penting, berharga, dan menyenangkan.

Implementasi TGT hampir sama dengan STAD tetapi menggantikan kuis dengan turnamen, dimana peserta didik memainkan game akademik dengan anggota tim lain untuk menyumbangkan poin bagi skor timnya. Peserta didik memainkan game ini bersama tiga atau empat orang pada "meja-turnamen", di mana peserta pada setiap meja mempunyai kemampuan yang homogen. Game akademik dengan banyak soal latihan dipandang sesuai dengan karakteristik belajar matematika yang menuntut peserta didik harus banyak mengerjakan soal latihan agar cepat hafal rumus-rumus yang digunakan dan proses pemahaman.

Dengan kombinasi STAD dan TGT guru berupaya dapat meningkatkan kualitas pembelajaran matematika, karena dengan kerja kelompok, kuis individu dan game akademik menyenangkan, dimungkinkan dapat membangkitkan motivasi dan aktivitas dengan menarik minat ataupun konsentrasi peserta didik terhadap materi yang sudah dan akan dipelajari peserta didik sejak awal pembelajaran hingga akhir pembelajaran. Pada akhir pembelajaran, guru juga perlu mengarahkan peserta didik tentang pentingnya belajar sungguh-sungguh agar di akhir pembelajaran dapat mencapai hasil optimal. Dalam hal ini selama proses pembelajaran matematika dapat dikemas menjadi suatu tindakan yang dapat menarik peserta didik untuk tetap bersemangat belajar matematika hingga akhir pembelajaran

Implementasi STAD dikombinasikan dengan TGT dianggap salah satu solusi yang dapat menyelesaikan 
masalah tersebut di atas dengan memperhatikan karakteristik bahwa kedua model pembelajaran tersebut harus menggunakan banyak latihan soal sebagai kuis individu, kegiatan kelompok dan game akademik.

\section{Motivasi dan Aktivitas Belajar}

Motivasi adalah dorongan yang timbul pada diri seseorang untuk melakukan suatu tindakan dengan tujuan tertentu yang dapat menyebabkan seseorang atau sekelompok orang tertarik dan tergerak untuk melakukan sesuatu karena ingin mencapai tujuan yang dikehendaki atau mendapatkan kepuasan dengan perbuatan (Poerwadarminto, 1995:593).

Sementara menurut Sardiman (2007:102): a) motivasi dapat diartikan daya penggerak yang ada dalam diri seseorang untuk melakukan aktivitas-aktivitas tertentu demi tercapainya suatu tujuan,.b) motivasi belajar dapat dikatakan sebagai keseluruhan daya penggerak di dalam diri siswa yang menimbulkan, menjamin kelangsungan dan memberikan arah kegiatan belajar, sehimgga diharapkan tujuan dapat tercapai., c) motivasi selalu terkait dengan kebutuhan, misal : kebutuhan untuk menyenangkan orang lain, kebutuhan untuk mencapai hasil, kebutuhan untuk mengatasi kesulitan. Sehingga motivasi mempunyai beberapa cirri-ciri antara lain: tekun menghadapi tugas, ulet menghadapi kesulitan
Berdasarkan pengertian tersebut di atas, dapat diambil kesimpulan bahwa motivasi belajar adalah dorongan atau kekuatan dalam diri peserta didik yang menimbulkan kegiatan serta arah belajarnya untuk mencapai tujuan yang dikehendaki. Menurut Sardiman (2007:103) mengemukakan ada tiga fungsi motivasi, yaitu: a) mendorong manusia untuk melakukan kegiatan, b) menentukan arah kegiatan yang harus dikerjakan sesuai dengan rumusan tujuannya, dan c) menyeleksi perbuatan dengan menentukan perbuatan yang harus dikerjakan yang sesuai untuk mencapai tujuan. Sedangkan bentuk-bentuk motivasi dalam belajar antara lain: member angka, hadiah, ego-involvemen, memberi ulangan, mengetahui hasil, pujian, hukuman, hasrat untuk belajar, minat.

Aktivitas belajar peserta didik adalah aktivitas yang bersifat fisik ataupun mental (Sardiman, 2007:99). Aktivitas belajar adalah serangkaian kegiatan fisik atau jasmani maupun mental atau rohani yang saling berkaitan sehingga tercipta belajar yang optimal. Dalam aktivitas belajar ini peserta didik haruslah aktif mendominasi dalam mengikuti proses belajar mengajar sehingga mengembangkan potensi yang ada pada dirinya sesuai dengan pandangan Ilmu Jiwa Modern. Dengan kata lain dalam beraktivitas peserta didik tidak hanya mendengarkan dan mencatat seperti (pandangan Ilmu Jiwa Lama), pembelajaran berlangsung didominasi 
oleg guru atau pembelajaran secara konvensional.

Sardiman (2007:22) menyatakan belajar merupakan suatu proses interaksi antara diri manusia dengan lingkungannya yang mungkin berwujud pribadi, fakta, konsep ataupun teori yang mengakibatkan terjadinya perubahan.tingkah laku.

Sehingga yang dimaksud aktivitas belajar peserta didik adalah seluruh kegiatan interaksi peserta didik dengan lingkungan baik fisik maupun psikis yang mengakibatkan perubahan tingkah laku, keterampilan, pengetahuan, pemahaman dari tidak tahu menjadi tahu.

\section{Model Pembelajaran Koopertif}

Pembelajaran kooperatif

(cooperative learning) merupakan bentuk pembelajaran dengan cara peserta didik belajar dan bekerja dalam kelompok kecil secara kolaboratif yang anggotanya terdiri dari empat sampai enam orang dengan struktur kelompok yang bersifat heterogen (Rusman 2011:203). Menurut Rusman (2011: 2018) unsurunsur dan ciri-ciri yang harus diperhatikan dalam pembelajaran kooperatif , peserta didik: (1) dalam kelompoknya haruslah beranggapan bahwa mereka sehidup sepenanggungan bersama.(2) bertanggung jawab atas segala sesuatu di dalam kelompoknya seperti milik mereka sendiri, (3) haruslah melihat bahwa semua anggota di dalam kelompoknya memiliki tujuan yang sama, (4) haruslah membagi tugas dan tanggung jawab yang sama diantara anggota kelompoknya, (5) akan dikenakan evaluasi atau diberikan hadiah/penghargaan yang juga akan dikenakan untuk semua anggota kelompok.

Memperhatikan uraian tersebut dalam sistem belajar yang kooperatif peserta didik memiliki dua tanggung jawab, yaitu mereka belajar untuk dirinya sendiri dan membantu sesama anggota kelompok untuk belajar.

\section{Model STAD}

Model STAD adalah model pembelajaran yang dikembangkan oleh Robert Slavin dan kolegakoleganya di Universitas John Hopkin, merupakan salah satu model yang banyak digunakan dalam pembelajaran kooperatif. Slavin (1995) menjelaskan bahwa pembelajaran kooperaritif dengan model STAD, peserta didik ditempatkan dalam kelompok belajar beranggotakan empat atau lima orang peserta didik yang mempunyai kemampuan akademik yang berbedabeda, sehingga dalam setiap kelompok terdapat peserta didik yang berprestasi tinggi, sedang, dan rendah atau variasi jenis kelamin, kelompok ras dan etnis, atau kelompok sosial lainnya. Guru menyajikan pelajaran, dan kemudian peserta didik bekerja dalam tim mereka memastikan bahwa seluruh anggota tim telah menguasai pelajaran tersebut. Kemudian, seluruh peserta didik diberikan tes (kuis individu) 
tentang materi tersebut, pada saat tes ini mereka tidak diperbolehkan saling membantu.

\section{Model TGT}

Model pembelajaran kooperatif tipe TGT adalah suatu model pembelajaran yang didahului dengan penyajian materi pembelajaran oleh guru dan diakhiri dengan memberikan sejumlah pertanyaan kepada peserta didik. Model ini dikembangkan secara asli oleh David De Vries dan Keath Edward (1995). Pada model ini peserta didik memainkan permainan dengan anggota-anggota tim lain untuk memperoleh tambahan poin untuk skor tim mereka.

TGT dapat digunakan dalam berbagai macam mata pelajaran, dari ilmu-ilmu eksak, ilmu-ilmu sosial maupun bahasa dari jenjang pendidikan dasar(SD,SMP) hingga perguruan tinggi. TGT sangat cocok untuk mengajar tujuan pembelajaran yang dirumuskan dengan tajam diadaptasi untuk digunakan dengan satu jawaban yang benar.

\section{Kombinasi STAD dan TGT}

Model Pembelajaran yang digunakan pada penelitian ini adalah kombinasi antara STAD dan TGT, maka dalam pembelajaran langkahlangkahnya adalah mengkombinasikan langkah-langkah model pembelajaran STAD dan TGT, untuk tahap yang sama diambil salah satu. Kegiatan inti tahap-tahap pembelajaran kombinasi model pembelajaran STAD dan TGT, sebagai berikut: 1) persentasi guru, 2) kegiatan kelompok (kelompok heterogen/kawan), 3) game turnamen (kelompok homogen/lawan), 4) kuis individu, dan 5) penghargaan kelompok. Dalam penerapannya lima tahap kegiatan pembelajaran tersebut tidak diterapkan semuanya dalam setiap kali pertemuan, tetapi setiap tahap diterapkan dalam satu kali pertemuan. Sehingga proses pembelajarn berlangsung sebagai berikut :

1. Pertemuan tatap muka pertama pembelajaran diawali (1)pendahuluan (2) presentasi guru untuk menemukan konsep-konsep untuk penerapan empat kali tatap muka. Presentasi guru dengan penemuan terbimbing, diskusi kelas, praktik, demonstrasi, pembelajaran langsung dan lainlain. (3)Peserta didik duduk bersama tim kerjanya dan merangkum semua konsep-konsep yang akan digunakan pada pertemuan tatap muka berikutnya.

2. Pertemuan tatap muka kedua peserta didik duduk sesuai dengan tim kerjanya (tim asli) diawali (1) apersepsi mengingat konsepkonsep yang telah ditemukan pada pertemuan sebelumnya, (2)kegiatan kelompok diskusi mengerjakan tugas penerapan konsep yang telah dipelajari pada tatap muka sebelumnya kerja kelompok dan (3) presentasi tim,(4)penghitungan skor Tim 
,(5)pemberian penghargaan Tim terbaik

3. Pertemuan tatap muka ketiga peserta didik duduk sesuai dengan kelompok game turnament (kemampuan homogen), (1)apersepsi, (2)game tournament,(3) penghitungan perolehan skor kemajuan Tim kerja, poin kemajuan tim dihitung dari selisih dengan nilai awal, (4)pemberian penghargaan Tim berprestasi

4. Pertemuan tatap muka keempat peserta didik duduk sesuai dengan kelompok game turnament, (1) apersepsi, (2) mengerjakan kuis individu/evaluasi mandiri, (3) saling tukar hasil tes untuk saling mengoreksi dan menilai, (4) penghitungan perolehan skor dan poin kemajuan dibandingkan dengan nilai awal,(5) pemberian penghargaan Tim berprestasi.

Penghargaan diberikan pada setiap akhir pembelajaran bagi tim berprestasi yaitu tim yang memeperoleh skor kemajuan tertinggi. Pembelajaran tatap muka yang ke-5 sama dengan langkah-langkat tatap muka ke-1, tatap muka ke-6 sama dengan langkah-langkah tatap muka ke-2,tatap muka ke-7 sama dengan langkah-langkah tatap muka ke-3, dan tatapmuka ke- 8 sama dengan langkahlangkah tatap muka ke-4 begitu seterusnya diulang sehinggga setiap periode terdiri dari empat tatap muka.

\section{METODE PENELITIAN} Jenis Penelitian

Jenis penelitian yang digunakan dalam penelitian ini penelitian kuantitatif, sedangkan pendekatan yang dilakukan yaitu Quasi Experimental Design. Dikatakan Quasi Experimental Design, karena dalam desain ini, semua variabel luar yang mempengaruhi jalannya eksperimen dapat dikontrol. Dengan demikian, validitas internal (kualitas pelaksanaan rancangan penelitian) dapat menjadi maksimal (Sugiyono, 2012). Adapun desain penelitian yang digunakan adalah Posttest-Only Control Design dengan desain sebagai berikut.

\begin{tabular}{|lll|}
\hline $\mathrm{R}$ & $\mathrm{X}$ & $\mathrm{O}_{1}$ \\
$\mathrm{R}$ & & $\mathrm{O}_{2}$ \\
\hline
\end{tabular}

$\mathrm{R}$ = Sampel yang dipilih secara purposive

$\mathrm{O}_{1}=$ Kelompok eksperimen (yang diberi pembelajaran Model STAD dan TGT)

$\mathrm{O}_{2}=$ Kelompok kontrol dengan pembelajaran konvensional

$\mathrm{X}=$ Pembelajaran dengan Model STAD dan TGT

Dalam desain ini terdapat dua kelompok yang masing-masing dipilih secara purposive (R). Kelompok pertama, kelompok eksperimen yaitu kelompok yang diberi perlakuan, sedangkan kelompok kedua, 
kelompok kontrol yaitu kelompok yang tidak diberi perlakuan. Sementara itu, pengaruh adanya perlakuan (treatment) adalah $\left(\mathrm{O}_{1}\right.$ : $\mathrm{O}_{2}$ ). Dalam penelitian ini treatment yang diberikan adalah mengikutsertakan peserta didik ke dalam pembelajran dengan Model kombinasi $S T A D$ dan TGT. Jika terdapat perbedaan motivasi dan aktivitas belajar yang signifikan antara kelompok eksperimen dan kelompok kontrol, hal ini berarti bahwa perlakuan yang diberikan berpengaruh secara signifikan.

\section{HASIL PENELITIAN}

Analisis deskriptif dalam bentuk tabel distribusi frekuensi memperlihatkan adanya rata-rata aktivitas dan motivasi belajar kelompok kontrol dan dan kelompok eksperimen sama-sama sudah cukup baik. Sebelum implementasi model pembelajaran kombinasi tipe STAD dan $T G T$ : (1)rata-rata motivasi belajar kelas kontrol 66,42 sedang rata-rata motivasi belajar kelas eksperimen 68,22 . Nilai $p$ (sig) pada $F$ adalah 0,051dan 0,051 >0,05 memakai equal variances assumed. nilai $\mathrm{p}$ (sig) pada $\mathrm{t}$ adalah 0,149 dan $0,149>0,05$ sehingga $\mathrm{H}_{\mathrm{o}}$ diterima $\mathrm{H}_{\mathrm{a}}$ ditolak, (2) rata-rata aktivitas belajar kelas kontrol 67,11 sedang rata-rata motivasi kelas eksperimen 70,00. Nilai $p$ (sig) pada F adalah 0,009 dan $0,009<0,05$ sehingga dengan not equal variances assumed didapat nilai p (sig) pada t adalah 0,254 dan 0,254
> 0,05 sehingga $\mathrm{H}_{0}$ diterima $\mathrm{H}_{\mathrm{a}}$ ditolak. Berarti tidak ada perbedaan rata-rata motivasi belajar maupun aktivitas belajar antara kelompok kontrol dan kelompok eksperimen sebelum implementasi model pembelajaran kombinasi $S T A D$ dan $T G T$.

Keadaan proses pembelajaran dengan model pembelajaran kombinasi STAD dan TGT berlangsung sangat kondusif. Diskusi kerja kelompok pada tim kerja berlangsung sangat komunikatif. Anggota kelompok dengan koqnitif level atas dengan sabar dan tekun membantu menerangkan kepada angota kelompok level bawah. Anggota kelompok level menengah juga tidak malu-malu bertanya jika kurang paham. Semua anggota kelompok berusaha bahwa pada turnamen dan juga kuis individu nanti, semua harus bisa mengerjakan soal dan dapat menyumbangkan nilai untuk timnya, sehingga timnya mencapai tim terbaik.

Kegiatan turnamen terlihat sangat mnyenangkan, Semua anggota turnamen terlihat wajah sangat mennyenangkan dengan semangat bertanding. Semua semangat merasa tertantang berusaha dengan sekuat tenaga untuk dapat menyelesaikan soal game sehingga nanti pulang dapat menyumbangkan nilai ke tim kerjanya. Semua berusaha dengan semangat dengan tekad jangan sampai pulang ke tim nya dengan tanpa membawa nilai. 
Pelaksanaan kuis individu semua peserta didik mengerjakan kuis dengan konsentrasi yang optimal. Peserta didik duduk seperti pada waktu turnamen, homogen (koqnitif) level atas dengan level atas, level bawah dengan level bawah, dan level tengah dengan level tengah. Tidak ada siswa yang saling bertanya ataupun saling mencontek karena mereka sadar bahwa teman didekatnya adalah lawannya dalam meraih predikat tim terbaik.

Akhirnya diperoleh hasil analisa data sesudah implementasi model pembelajaran kombinasi tipe STAD dan $T G T$ :(1)rata-rata motivasi belajar kelas kontrol 67,07, sedang rata-rata motivasi kelas eksperimen 82,46. Nilai $p$ (sig) pada F adalah 0,511 dan $0,511>0,05$ memakai equal variances assumed (data diasumsikan homogen) nilai $\mathrm{p}$ (sig) pada $\mathrm{t}$ adalah 0,000 dan $0,000<0,05$ sehingga $\mathrm{H}_{\mathrm{o}}$ ditolak $\mathrm{H}_{\mathrm{a}}$ diterima, (2)rata-rata aktivitas belajar kelas kontrol 68,90, sedang rata-rata aktivitas belajar kelas eksperimen 85,46. Nilai p (sig) pada $F$ adalah 0,138 dan 0,138>0,05 dengan menggunakan equal variances assumed (data diasumsikan homogen) nilai $\mathrm{p}$ (sig) pada $\mathrm{t}$ adalah 0,000 dan $0,000<0,05$ sehingga $\mathrm{H}_{\mathrm{o}}$ ditolak $\mathrm{H}_{\mathrm{a}}$ diterima. Didapat kesimpulan ada perbedaan rata-rata motivasi belajar maupun aktivitas belajar yang signifikan antara kelompok kontrol dan kelompok eksperimen. Juga peningkatan rata-rata motivasi dan aktivitas belajar kelas eksperimen lebih tinggi dari kelas kontrol setelah implementasi model pembelajaran kombinasi tipe $S T A D$ dan $T G T$.

Aktivitas mental dan psikis yang berlangsung dalam interaksi aktif dengan lingkungan yang menghasilkan perubahan dalam pengetahuan, pemahaman, ketrampilan, dan nilai sikap. Semakin banyak terlibat dalam aktivitas belajar yang ditandai dengan interaksi antara diri manusia dengan lingkungannya yang mungkin berwujud pribadi, fakta, konsep ataupun teori, maka perubahan akan semakin mudah dicapai. Depdiknas (2005:31), belajar aktif adalah suatu sistem belajar mengajar yang menekankan keaktifan peserta didik secara fisik, mental intelektual dan emosional guna memperoleh hasil belajar berupa perpaduan antara aspek kognitif, afektif dan psikomotor.

Hasil uji beda dengan rumus ttes memperlihatkan bahwa Nilai $p$ (sig) pada $\mathrm{t}$ adalah $0,000<0,05$ sehingga ada perbedaan rata-rata motivasi antara kelompok kontrol dan kelompok eksperimen setelah implementasi model STAD dan TGT. Nilai p (sig) pada $\mathrm{t}$ adalah $0,000<$ 0,05 sehingga ada perbedaan rata-rata aktivitas antara kelompok kontrol dan kelompok eksperimen setelah implementasi STAD dan TGT. Peningkatan motivasi karena model STAD dan TGT menghasilkan lingkungan belajar yang memungkinkan terjadinya interaksi di antara para peserta didik sekaligus juga kompetisi yang mendorong para 
peserta didik untuk meningkatkan aktivitasnya. Pada saat belajar di kelompoknya masing-masing, peserta didik yang tidak paham dituntut untuk bertanya dan menyimak penjelasan dari teman di kelompoknya, sebaliknya peserta didik yang sudah paham berusaha memastikan setiap anggota di kelompoknya bisa menguasai materi yang dipelajari. Tantangan untuk memenangkan kuis menjadi daya tarik bagi setiap peserta didik di masing-masing kelompok untuk meningkatkan aktivitasnya. Demikian pula pada saat tournamen, maka setiap peserta didik yang mewakili kelompok tertantang untuk memenangkan tournamen tersebut.

\section{KESIMPULAN DAN SARAN Kesimpulan}

Berdasarkan hasil penelitian dan pembahasan tentang pembelajaran matematika dengan model STAD dikombinasikan dengan TGT di SMP Negeri 3 Bantul dapat ditarik kesimpulan sebagai berikut:

1. Ada perbedaan motivasi belajar peserta didik yang belajar dengan model pembelajaran tipe $S T A D$ dikombinasikan dengan $T G T$ dengan peserta didik yang belajar dengan model pembelajaran konvensional dalam kegiatan belajar matematika di kelas IX SMP 3 Bantul. Hasil uji beda dengan rumus t-tes memperlihatkan bahwa Nilai $p$ (sig) pada $\mathrm{t}$ adalah 0,000 dan $0,000<\quad 0,05$ sehingga ada perbedaan rata-rata motivasi antara kelompok kontrol dan kelompok eksperimen setelah implementasi model pembelajaran kombinasi tipe $S T A D$ dan $T G T$.

2. Ada perbedaan aktivitas belajar peserta didik yang belajar dengan model pembelajaran tipe $S T A D$ dikombinasikan dengan TGT dengan peserta didik yang belajar dengan model pembelajaran konvensional dalam kegiatan belajar matematika di kelas IX SMP 3 Bantul. Nilai $\mathrm{p}$ (sig) pada $\mathrm{t}$ adalah 0,000 dan $0,000<0,05$ sehingga ada perbedaan rata-rata aktivitas belajar antara kelompok kontrol dan kelompok eksperimen setelah implementasi model pembelajaran kombinasi tipe STAD dan TGT.

3. Peserta didik kelas IX SMP 3 Bantul yang belajar matematika dengan model pembelajaran tipe STAD dikombinasikan dengan TGT mengalami peningkatan ratarata motivasi belajar lebih tinggi dari pada peserta didik yang belajar dengan model pembelajaran konvensional.

4. Peserta didik kelas IX SMP 3 Bantul yang belajar matematika dengan model pembelajaran tipe STAD dikombinasikan dengan TGT mengalami peningkatan ratarata aktivitas belajar lebih tinggi dari pada peserta didik yang belajar dengan model pembelajaran konvensional. 
Saran

1. Sebaiknya guru matematika lebih sering mengimplementasikan model-model pembelajaran kooperatif agar peserta didik lebih aktif dan termotivasi untuk berpartisipasi dalam kegiatan pembelajaran.

2. Sebaiknya pembelajaran kooperatif dijalankan secara bervariatif agar para peserta didik memiliki kekayaan pengalaman pembelajaran matematika dan tidak membosankan.

\section{DAFTAR PUSTAKA}

Abdulhak, Ishak. 2000. Metodologi Pembelajaran. Bandung : Andira.

Ngalim Purwanto. 2002. Psikologi Pendidikan. Bandung : PT. Remaja Rosdakarya.
Rusman. 2011. Model-model Pembelajaran, Jakarta : Rajawali Pers.

Sardiman, AM.. 2007. Interaksi dan Motivasi Belajar Mengajar. Jakarta: PT Raja Grafindo Persada.

Silberman, Melvin L. 2006. Active Learning: 101 Cara Belajar Siswa Aktif. Alih Bahasa Raisul Muttaqien. Bandung: Nusa Media dan Nuansa.

Slavin Robert E. 2005. Cooperative Learning: theoryesearch and practice. Alih Bahasa Narulita Yusron, Bandung: Nusa Media.

Sugiyono. 2012. Metode Penelitian Pendidikan, Bandung, Alfabeta 